\title{
On the Issues of Using Factor Analysis of the Financial Results of the Organization in the Agricultural Sector of the Economy
}

\author{
Nadezhda Klimovskikh \\ Department of Economic Theory \\ FSBI of HE Kuban State Agrarian University named after \\ I.T. Trubilin \\ Krasnodar, Russia \\ Nadin180676@yandex.ru
}

\author{
Andrei Fediashkin \\ Department of Finance and credit \\ FSBI of HE Kuban State Agrarian University named after \\ I.T. Trubilin \\ Krasnodar, Russia \\ andrejj443@gmail.com
}

\begin{abstract}
The article focuses on the importance of applying factor analysis of financial results in the activities of organizations worked in the agricultural sector. The agricultural sector of the economy is a complex multisectoral productiveeconomic system. The level of its development largely determines the level of food security of the country, its political and economic stability. In this regard, there is an objective necessity to provide the stability of the development of agricultural enterprises. The value of the financial result of the organization is an indicator that is influenced by many factors, including specific, distinctive to a particular industry. In this connection, the implementation of factor analysis of profit in the context of the main types of production is an important element in the development of the marketing strategy of the company. The economic and financial development, financial incentives for employees depend on the size of the organization's profit, and profitability indicators allow the manager to assess the effectiveness of the organization and make a policy decision. A factor analysis, based on the example of one of the operating enterprise of the Krasnodar Territory, was carried out, as a result of which the influence of the quantity, cost, price and assortment of goods sold on the profit from the sale of wheat was revealed. As a result of the research, a number of issues were identified. The key issues are: a growth of material production costs for wheat, and also an insufficient price policy. The reserves of the organization's profit growth were determined and the possible economic effect of additional activities, which lie in the implementation of the strain renovation and the actualization of additional volume of wheat at higher prices, was calculated.
\end{abstract}

Keywords- price; sales figure; proceeds; cost; sales profit; factor analysis

\section{INTRODUCTION}

Information on the financial results of the activities of economic entities has always been a value both in the process of managing their activities and in the process of evaluating the effectiveness of functioning, planning the prospects for their development, expanding the scope of work and many other goals. Contributions from profit to the budget serve as a source for the implementation of local and national programs [1]. At the same time, the food security of the country depends on the profitability of the activities of agricultural organizations. That is why the issue of choosing a tool for analyzing factors influencing profit, as well as justifying the reserves for its growth, should be given due attention. According to the statistics, currently, not all organizations in the agricultural industry implement a break-even activity. In this regard, it is necessary to analyze the factors that influence the formation of the financial result.

There are many approaches to implement the factor analysis. Depending on the specifics of the economic entity, as well as the forms of financial statements, it is possible to determine in varying degrees of accuracy the sources of financial issues and the degree of their impact on the profit of the organization. In the article the price and non-price aspects of the profit formation of an agricultural organization are considered, including the analysis of statistical indicators depending on the scale of the market.

\section{MethodS AND RESUlTS}

The categorical apparatus of mathematical factor analysis is presented in the works of H. Kaiser, C. Pearson, R. Tucker, R. Thurstone G. Harman, G. Hotelling [2] [3] [4] [5] [6] [7]. Aspects of the factor analysis of the financial results of economic entities are investigated in the works of $\mathrm{V}$. Gorfinkel, N. Zimin, A. Kanke. G. Savitskaya, I. Sergeeva [8] [9] [10] [11] [12].

In the article the methods of systemic, monographic, statistical, economic and mathematical research are used. Each of the methods is used according to its functionality. 
conscience of the manufacturer. As a result, the collective management experience for Russia is a passed stage, collective farms had their own advantages, a return to which is possible, but long-term and is connected with the regulation of the legal mechanism. At the same time, the problem of the present day is the nominal enlargement of farms; investors who are not related to a given industry or region come to the agricultural market, and buying up the property of many small and medium-sized entities, thereby monopolizing local trade zones [17].

The economic mechanism is implemented mainly through government programs for the development of agriculture and the regulation of the market for raw materials and food. The last such program was adopted for the period from 2013 to 2020, but was almost changed and refined annually, its directions, forms, and mechanisms, as well as the volumes of state support [18]. According to the tasks that the industry faces, it is necessary to achieve proportionality between the goals set before the agro-industrial complex and the financial resources allocated for their solution.

Comparing the growth rates of producer prices in agriculture and industry over the past few years, it can be observed that the last is occupied the prevailing position. In this connection, there is a need to limit the growth of prices for material and technical resources [19].

In Russia, agricultural production has certain tax exemptions [20]. However, according to a comparison of the tax burden on agricultural organizations with the EAEU countries, it turns out that it is higher than average [21].

Climate factors influence on the activities of agricultural organizations a lot. In the long turn, they can lead to a change in the system of agricultural production, its distribution in the country's zones, the need for new approaches to crop breeding, and the technological justification in the industry [22].

Especially, particular importance in the process of evaluating the effectiveness of production, the level of its reliability has the financial results. They reflect all items of income and expenses of the organization, as well as summarize the results of activities [23].

\section{RESULTS}

A detailed analysis of the financial results was carried out on the example of the agricultural organization of the Krasnodar Territory, the main activity of which is the cultivation of winter wheat.

As the sources of analysis data, the annual financial statements of the organization for 2016-2018 were used, including: a report on financial results; report on production, expenses, costs, expenses and sales of crop production [24] [25].

Referring to the calculation part, the performance indicators of the wheat sales of the organization under study over the years, Table I, should be considered. Thus, an increase in the volume of sales by $34.2 \%$ can be argued that 2018 , although it turned out to be unfavorable in climatic enter the market and stay on existing ones - as a result, quality and price of the products fall entirely on the 
The increase in the prices of the research object had a terms, but at the same time distinguished by a larger sowing area, and the impact of adverse rainfall was minimal [26] [27].

TABLE I. THE PERFOMANCE INDICATORS OF THE WINTER WHEAT SALES OF THE ORGANISATION

\begin{tabular}{|l|l|l|l|l|}
\hline \multirow{2}{*}{ Indicator } & \multirow{2}{*}{$\mathbf{2 0 1 6}$} & \multirow{2}{*}{$\mathbf{2 0 1 8}$} & \multicolumn{2}{c|}{ Variance } \\
\cline { 4 - 6 } & & & \multicolumn{1}{|c|}{ \pm} & \multicolumn{1}{c|}{$\%$} \\
\hline Quantity of products sold, hwt & 534444 & 717012 & 182568 & 134.2 \\
\hline Sell price rubles/hwt & 873.90 & 1084.24 & 210.34 & 124.1 \\
\hline Full cost price, thousand rubles & 259515 & 356185 & 96670 & 137.3 \\
\hline Proceeds, thousand rubles & 467027 & 777410 & 310383 & 166.5 \\
\hline Income, thousand rubles & 207512 & 421225 & 213713 & By 2.03 \\
\hline Level of profitability, \% & 44.43 & 54.18 & 9.75 & X \\
\hline Source: compiled by the authors & \multicolumn{4}{|l}{} \\
\hline
\end{tabular}

A $24.1 \%$ price increase identified the general market trends [28]. External reasons for the growth of the indicator were long periods of drought, a forecast of reduced gross grain harvest, devaluation of the national currency and rising prices in the global market. Internal factors also had equally impact production technology affects.

Comparing the dynamics of prices for winter wheat of the 3-4th grade of the studied organization with the average annual prices for Russia, the Southern Federal District and the Krasnodar Territory, it can be stated that it has a predominant nature in the framework of 2016-2018. [29]. In absolute terms, in 2017 and 2018 the price was also the highest, Table II.

TABLE II. COMPARATIVE ASSESSMENT OF THE WINTER WHEAT PRICES DYNAMICS

\begin{tabular}{|c|c|c|c|c|c|}
\hline \multirow{2}{*}{ Markets } & \multicolumn{4}{|c|}{ Price, RUB } & \multirow{2}{*}{$\begin{array}{l}\text { Growth } \\
\text { rate\% }\end{array}$} \\
\hline & 2016 & 2017 & 2018 & 2019 & \\
\hline Russian Federation & 883.7 & 730.4 & 853.7 & 1044.2 & 118.16 \\
\hline $\begin{array}{ll}\text { Southern } & \text { Federal } \\
\text { District } & \end{array}$ & 928.6 & 827.7 & 965.0 & 1083.1 & 116.63 \\
\hline Krasnodar Territory & 957.5 & 872.5 & 1011.0 & 1116.7 & 116.62 \\
\hline Organization & 873.9 & 881.1 & 1084.2 & - & - \\
\hline
\end{tabular}

Having data on average prices for different markets for 9 months of 2019, it can be said about the falling character of the indicator as a whole, which should eventually affect the reaction of the organization, Figure 1 [30].

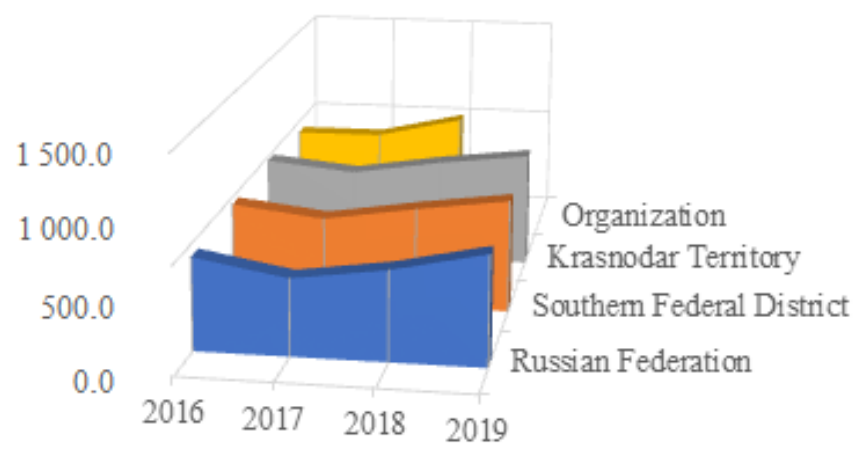

Fig. 1. Comparative assessment of the winter wheat prices dynamics (Source: compiled by the authors) positive effect on the proceeds. As a result of high growth in sales and prices, the company's proceeds increased by $66.5 \%$.

Largely because of the reasons associated with the growth of material costs, the cost of production and sale of wheat increased by $37.3 \%$. In considering the cost structure more specifically, private articles, which have influenced this growth, can be distinguished. Detalization of the aggregate costs is presented in Table III.

\section{TABLE III. COST STRUCTURE OF THE ORGANIZATION FOR} PRODUCTION AND SALES OF THE WINTER WHEAT

\begin{tabular}{|l|l|l|l|c|c|c|}
\hline \multirow{2}{*}{ Input item } & \multicolumn{2}{|c|}{$\mathbf{2 0 1 6}$} & \multicolumn{2}{c|}{$\mathbf{2 0 1 8}$} & \multicolumn{2}{c|}{ Variance } \\
\cline { 2 - 7 } & $\begin{array}{c}\text { Thous. } \\
\text { RUB }\end{array}$ & $\%$ & $\begin{array}{c}\text { Thous. } \\
\text { RUB }\end{array}$ & $\%$ & \pm & $\%$ \\
\hline $\begin{array}{l}\text { Aggregate costs, } \\
\text { Thousand rubles }\end{array}$ & 259515 & 100.0 & 356185 & 100.0 & 96670 & 137.2 \\
\hline $\begin{array}{l}\text { including: } \\
\text { I Costs for sales, } \\
\text { Thousand rubles }\end{array}$ & 41092 & 15.8 & 12903 & 3.6 & -28189 & 31.4 \\
\hline $\begin{array}{l}\text { II Production costs, thousand } \\
\text { rubles }\end{array}$ & 218423 & 84.2 & 343282 & 96.4 & 859 & 157.2 \\
\hline $\begin{array}{l}\text { among them: } \\
\text { 1) Remuneration }\end{array}$ & 18562 & 7.2 & 20635 & 5.8 & 2073 & 111.2 \\
\hline 2) Material costs & 181146 & 69.8 & 208269 & 58.5 & 27123 & 114.9 \\
\hline 2.1) for seeds & 12428 & 4.8 & 23101 & 6.5 & 10673 & 185.9 \\
\hline $\begin{array}{l}\text { including: } \\
\text { 2.1.1) elite }\end{array}$ & 9374 & 3.6 & 0 & 0.0 & -9374 & - \\
\hline 2.2) mineral fertilizers & 71079 & 27.4 & 77545 & 21.8 & 6466 & 109.1 \\
\hline 2.3) plant protection products & 32545 & 12.5 & 41555 & 11.7 & 9010 & 127.7 \\
\hline 2.4) oil -products of all types & 16932 & 6.5 & 20396 & 5.7 & 3464 & 120.5 \\
\hline $\begin{array}{l}\text { 2.5) supplies of the main } \\
\text { financial resources }\end{array}$ & 48162 & 18.6 & 45672 & 12.8 & -2490 & 94.8 \\
\hline 3) Costs for insurance & 18715 & 7.2 & 0 & 0.0 & -18715 & - \\
\hline $\begin{array}{l}\text { 4) Other costs } \\
\text { Source: compiled by the authors }\end{array}$ & 0 & 0.0 & 114378 & 32.1 & 378 & - \\
\hline
\end{tabular}

Despite the small proportion of the structure, the maximum absolute and relative increase are clearly traced by the input item of seed, $86.9 \%$ growth. Moreover, elite varieties of wheat in the reporting year ceased to be purchased by the organization, the emphasis was placed on 3-4 grades. increased. Outstripping the rate of proceeds growth over cost by 29 percentage points led to an increase in the nominal positive financial result of the organization by more than twice over the period, and the real one - by 9.75 percentage points.

Based on the above, it should be noted that the organization's activities are profitable, but at the same time not fully effective, especially in the sense that the grain growing sub-sector in the Krasnodar Territory remains one of the leading and plays an important role in ensuring the country's food security, and also has high potential for development [31]. In this regard, a tool to analyze the impact of key factors on the profit of the organization should be used. Among the many approaches, based on the indicator and the specifics of the organization, the most suitable method is by G. Savitskaya [11].
Nevertheless, the sales efficiency of the main product has 
seeds in wheat production can be determined. A business case is given in Table 6 .

So, under the project, the purchase and sowing of seeds of winter wheat of the 1-2 grade to a predominant degree towards to the varieties of 3-4 grade in 2018 would allow the organization to increase the gross output from 1 hectare by $14.9 \%$ [32]. And with a fixed value of the price and an increase in total costs by $9.9 \%$ (or 35163 thousand rubles), it can reduce the cost of sales of 1centner of the final product by $4.4 \%$, thereby cutting the profit from wheat sales by $19.2 \%$ (or 81024 thousand rubles). In this case, a real increase in economic benefits could amount to 2.02 percentage points.

TABLE IV. RAW DATA FOR THE FACTOR ANALYSIS OF THE ORGANIZATION'S PROFIT FROM THE SALE OF WINTER WHEAT

\begin{tabular}{|c|c|c|c|c|c|c|}
\hline \multirow{3}{*}{ Product } & \multicolumn{2}{|c|}{$\begin{array}{c}\text { Quantity of sold, } \\
\text { hwt }\end{array}$} & \multicolumn{2}{|c|}{$\begin{array}{c}\text { Cost price } 1 \text { hwt, } \\
\text { RUB }\end{array}$} & \multicolumn{2}{|c|}{$\begin{array}{c}\text { Price for } \\
1 \text { hwt, RUB }\end{array}$} \\
\hline & 2016 & 2018 & 2016 & 2018 & 2016 & 2018 \\
\hline & $q_{0}$ & $q_{1}$ & $z_{0}$ & $z_{1}$ & $p_{0}$ & $p_{1}$ \\
\hline Wheat & 534444 & 717012 & 485.58 & 496.76 & 873.86 & 1084.24 \\
\hline
\end{tabular}

Source: compiled by the authors

By sequentially calculating the indicators, the magnitude of the influence of each factor in monetary terms was determined. The result of factor analysis is shown in Table 5.

TABLE V. RESULTS OF THE FACTOR ANALYSIS OF THE ORGANIZATION'S PROFIT FROM THE SALE OF WINTER WHEAT

\begin{tabular}{|c|c|c|c|c|}
\hline \multicolumn{5}{|c|}{ Change in income, thousand RUB $( \pm)$} \\
\hline \multirow{2}{*}{$\Delta \boldsymbol{P}$} & $\boldsymbol{q}$ & $\boldsymbol{z}$ & $\boldsymbol{p}$ & structure \\
\cline { 2 - 5 } & 13393.10 & -8016.62 & 150844.89 & 57491.63 \\
\hline 213713 & Source: compiled by the authors \\
\hline
\end{tabular}

So, in general, the profit from the sale of wheat for three years has changed by 213713 thousand rubles. Of this amount, the greatest positive effect was exerted by an increase in the price of wheat 1centner, as a result of which the financial result increased by 150844.89 thousand rubles. To a lesser extent, the number of products sold in physical terms (13 393 thousand rubles) and an increase in the level of profitability relative to other types of products (57 491.63 thousand rubles) influenced profit growth.

Only the increase in the cost of 1 hwt of wheat had a negative effect, the financial result decreased by 8016.62 thousand rubles. That is, the most significant reserves for the organization's profit growth were optimization of production costs and pricing policy adjustment.

An increase in the volume of sales of wheat at a price that is too high relative to the market, or at a price that disproportionately covers the cost price of a production unit, will not lead to a significant positive effect or a positive result will not be achieved at all. Therefore, in the first place, it is advisable to use internal reserves. Changes in production technology can be .among them.

Based on the results of factor analysis of profit and structural study of cost price, the feasibility of using elite
TABLE VI. COMPARISON OF WINTER WHEAT PRODUCTION TECHNOLOGIES IN THE ORGANISATION

\begin{tabular}{|c|c|c|c|c|}
\hline \multirow[b]{2}{*}{ Indicator } & \multirow{2}{*}{\begin{tabular}{|c|} 
Existing \\
production \\
technology, \\
2018 \\
\end{tabular}} & \multirow{2}{*}{\begin{tabular}{|c|} 
Suggested \\
production \\
technology, \\
2018 (project) \\
\end{tabular}} & \multicolumn{2}{|c|}{ Variance } \\
\hline & & & \pm & $\%$ \\
\hline Crop acre, hectare & 9618 & 9618 & - & - \\
\hline $\begin{array}{ll}\text { Crop } & \text { yields } \\
\text { hwt/hectare }\end{array}$ & 74.64 & 85.80 & 11.16 & 114.9 \\
\hline Gross output, hwt & 717928 & 825224 & 107296 & 114.9 \\
\hline Products sold, hwt & 717012 & 824172 & 107160 & 114.9 \\
\hline $\begin{array}{ll}\text { Aggregate } & \text { costs, } \\
\text { thousand rubles }\end{array}$ & 356185 & 391348 & 35163 & 109.9 \\
\hline $\begin{array}{l}\text { including: } \\
-\quad \text { costs for sales, } \\
\text { thousand rubles }\end{array}$ & 12903 & 14831 & 1928 & 114.9 \\
\hline $\begin{array}{l}- \text { production costs, } \\
\text { thousand rubles }\end{array}$ & 343282 & 376516 & 33234 & 109.7 \\
\hline $\begin{array}{l}\text { among them: } \\
\text { - costs for seeds, } \\
\text { thousand rubles }\end{array}$ & 23101 & 42729 & 19628 & 185.0 \\
\hline $\begin{array}{l}\text { Cost price of sales } 1 \\
\text { hwt, thousand rubles }\end{array}$ & 496.76 & 474.84 & -21.92 & 95.6 \\
\hline $\begin{array}{lrr}\text { Cost price } & \text { of } \\
\text { production } & 1 & \text { hwt, } \\
\text { rubles } & & \\
\end{array}$ & 478.16 & 456.26 & -21.90 & 95.4 \\
\hline Cost for sales, rubles & 1084.24 & 1084.24 & 0.00 & - \\
\hline $\begin{array}{ll}\begin{array}{l}\text { Proceeds, } \\
\text { rubles }\end{array} & \text { thousand } \\
\end{array}$ & 777410 & 893596 & 116186 & 114.9 \\
\hline $\begin{array}{ll}\text { Income, } & \text { thousand } \\
\text { rubles } & \end{array}$ & 421225 & 502249 & 81024 & 119.2 \\
\hline $\begin{array}{l}\text { Profitability level of } \\
\text { production, } \%\end{array}$ & 54.18 & 56.21 & 2.02 & $X$ \\
\hline Source: compiled by th & he authors & & & \\
\hline
\end{tabular}

Also, the results of factor analysis and research on the dynamics of prices for winter wheat for 2016-2019 allowed to substantiate another proposal. Thus, the organization could use an increased $14.9 \%$ (107296 hwt) gross output of winter wheat as a reserve for sale in the next period at higher prices, especially considering that the annual loading of the elevator belonging to the object of study is not higher than $75 \%$ and the fact that, under conditions, this type of product can be stored for 10 years [33]. So, selling wheat of 1-2 grades at the average annual price of the Krasnodar Territory in 1 square meter 2019 (1116.7 rubles/hwt), the organization could additionally receive economic benefits in the amount of 119 817 thousand rubles. 
[16] N.F. Zaruk, "Osobennosti nalogooblazheniya sel'skogo khozaystva v stranakh EAES," APK: ekonomika i upravleniye. vol. 2, 2017, pp. 3340.

The implementation of these recommendations will allow the agricultural organization in the study to increase the type of financial condition to the maximum possible.

Thus, it is necessary to emphasize the importance of factor analysis of the financial results of agricultural organizations. Revealed reserves of profit growth will allow business entities to increase the efficiency of their activities.

The country's food security largely depends not only on ongoing state programs in the agricultural sector, but also on the individual effectiveness of each agricultural producer. On the example of the agricultural organization of the Krasnodar Territory, the effectiveness of factor analysis has been proved and new ways of profit growth have been justified.

\section{REFERENCES}

[1] A.P. Balashov, "Pribyl kak osnovnoy istochnik razvitiya sel'skokhozaystvennykh organisatsyy," sel'skokhozaystvennyh i pererabatyvayushchikh predpriyatiy, vol. 5, 2019, pp. 36-40.

[2] K. Pearson, Karl Pearson's Early Statistical Papers, vol. 2, 1956, p. 557.

[3] H. Harman, "Modern factor analysis," University of Chicago Press, 1976, p. 487.

[4] H. Kaiser, "The application of electronic computers to factor analysis," Educational and Psychological Measurement, vol. 20, 1960, pp. 141151.

[5] L. Tucker, R. Koopman, R. Linn, "Evaluation of factor analytic research procedures by means of simulated correlation matrices", Psychometrika, vol. 34, 1969, pp. 421-459.

[6] L. Thurstone, "Multiple factor analysis," Psychological Review, vol. 38(5), 1931, pp. 406-427.

[7] H. Hotelling, "The relations of the newer multivariate statistical methods to factor analysis," British Journal of Statistical Psychology, vol. 10, 1957, pp. 69-79.

[8] V.Y. Gorfinkel', Ekonomika organizatcii: uchebnik, 2017, p. 608.

[9] N.E. Zimin, Analiz i diagnostika finansovo-khoziaystvennoy deiatel'nosti predpriiatiia: uchebnik, 2004, p. 382.

[10] A.A. Kanke, Analiz finansovo-khoziaystvennoy deiatel'nosti predpriiatiia: ucheb. posobie, 2017, p. 288.

[11] G.V. Savitskaya, Analiz khozaystvennoy deyatel'nost: ucheb. posobie, 2017, p. 286.

[12] I.V. Sergeev, Ekonomika organizatcii (predpriiatiia): uchebnik, 2016, p 511.

[13] Delovoe informatcionnoe prostranstvo RBK (http://www.rbc.ru - Data obrashcheniya: 25.10.2019)

[14] P. Krause, E. Madelénat, S. N'Sondé, "Global outlook for the agri-food sector within a protectionist environment," Coface Economic Publications, 2019, p. 16.

[15] A.G. Samsonova, "Znacheniye faktornogo analiza pribyli ot prodazh v otsenke effektivnosti deyatel'nosti predpriyatiya," Colloquim-Juornal, vol. 7, 2019, pp. 97-99.

[17] I.K. Dashkovskii, "Otvergnutoe edinenie. Pochemu ideia kooperatcii plokho prizhivaetsa v rossiiskom sel'skom khoziaistve," Agrotekhnika I tekhnologii, vol.1, 2018.

[18] Gosudarstvennaya programma razvitiya sel'skogo khozaystva i regulirovaniya rynkov sel'skokhozaystvennoy produktsii, syrya i prodovol'stviya na 2013-2020 gody: utv. Postanovleniyem Pravitel'stva

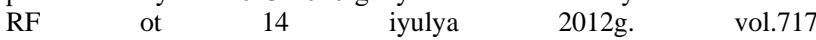
(http://gov.garant.ru/SESSION/PILOT/main.htm - Data obrashcheniya: 25.10.2019)

[19] Universitetskaya informatsionnaya sistema ROSSIYA (http://www.uisrussia.ru - Data obrashcheniya: 25.10.2019).

[20] V.D. Krivov, "O dolgosrochnoy strategii razvitiya agropromyshlennogo kompleksa Rossiyskoy Federazii," Analiticheskiy vestnik Soveta Federazii, vol. 10(699), 2018.

[21] I.G. Ushachev, Strategicheskie napravleniya razvitiya sel'skogo khozaystva Rossii v usloviyakh integratsii v EAES: electronniy sbornik, 2018, p. 48.

[22] O.S. Sobolev, Tsenovaya strategiya agrarnykh rynkov v usloviyakh dolgosrochnykh klimaticheskikh izmeneniy i tseny $\mathrm{v}$ pervom kvartale 2019 goda, Ekonomika sel'skokhozaystvennykh i pererabatyvayushchih predpriyatiy, vol. 6, 2019, pp. 67-72.

[23] Y.A. Rahmatullin, "Predposylki i analiz vozdeystviya faktorov na okupayemost' zatrat na proizvodstvo i realizatsiyu produktsii v sel'skom khozaystve," Ekonomika sel'skokhozaystvennykh pererabatyvayushchih predpriyatiy, vol. 3, 2019, pp. 58-61.

[24] Prikaz Minsel'khoza Rossii ot 10.01.2019 vol.4 "Ob utverjdenii form otchotnosti za 2018 god» (zareg. v Minyuste Rossii 29.01.2019 53599) (http://www.consultant.ru/cons/cgi/online.cgireq=doc\&base=LAW\&n=3 $17221 \&$ fld $=134 \& d s t=100001,0 \&$ rnd $=0.9777074444373964 \# 053790944$ 60312481 - Data obrashcheniya: 25.10.2019).

[25] Interfaks - Tsentr raskrytiya korporativnoy informatsii (https://www.edisclosure.ru - Data obrashcheniya: 25.10.2019)

[26] M.E. Yakovenko, Doklad ob osobennostyakh klimata na territorii Rossiyskoy Federazii za 2018 god: electronniy sbornik, 2019, p. 79.

[27] Arkhiv pogody po regionam RF s 2013 g. po 2019 g. (http://www.meteo9.ru - Data obrashcheniya: 25.10.2019).

[28] Obzor rynkov za 2018 god. Ministerstvo sel'skogo khozaystva Rossiyskoy Federazii (http://www.mcx.ru - Data obrashcheniya: 25.10.2019).

[29] Federal'naya sluzhba gosudarstvennoy statistiki Rossii (http://www.gks.ru - Data obrashcheniya: 25.10.2019).

[30] Institut Kon"yuktury Agrarnogo Rynka (http://www.ikar.ru - Data obrashcheniya: 25.10 .2019 ).

[31] T.M. Raybchenko, "Primeneniey faktornogo analiza v izucheni rezul'tatov proizvodstvenno-khozaystvennoy deyatel'nosti kommercheskoi organizatsii Krasnodarskogo kraya," Ekonomika i sotsium, vol. 6, 2016, pp. 537-541.

[32] Federal'nyiy tsenter kosul'tirovaniya agropromyshlennogo kompleksa (http://www.mcx-consult.ru - Data obrashcheniya :25.10.2019).

[33] O.S. Sobolev, "Faktory tsenoobrazovaniya na rynkakh prodovol'stviya $v$ 3-em kvartale 2018 goda," Ekonomika sel'skokhozaystvennykh i pererabatyvayushchih predpriyatiy, vol. 1, 2019, pp.78-83. 